\title{
Kernos
}

Revue internationale et pluridisciplinaire de religion grecque antique

1 | 1988

Varia

\section{The Rediscovery of the Greek Sanctuaries}

\section{Frieda Vandenabeele}

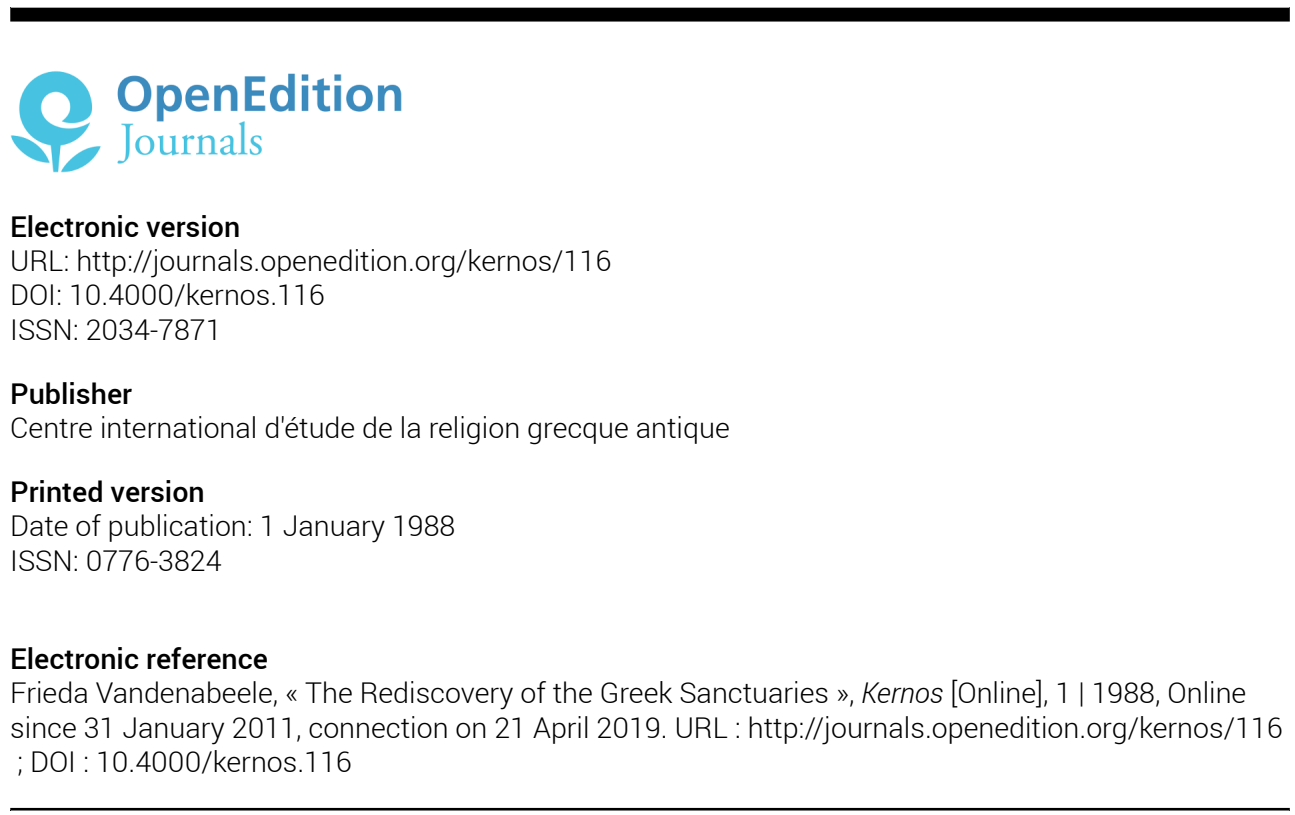

Kernos 
Kernos, 1(1988), p. 215-222.

\section{THE REDISCOVERY OF THE GREEK SANCTUARIES}

\section{( A LECTURE )}

\section{Ladies and Gentlemen, My Dear Colleagues,}

When my Greek and Belgian friends asked me to present a lecture within the scope of the colloquium «La pluridisciplinarité dans l'étude de la religion grecque antique» I felt quite honoured, but at the same time I also felt a bit incomfortable as I am not a specialist in Greek religion. After giving the matter some thought, I opted for an archaeological subject linked to religion, to wit «The rediscovery of the Greek Sanctuaries» including that of major more or less isolated temples.

The first post-antique information was provided by Cyriacus of Ancona who visited Athens between 1443 and 1447. Copies of some of his drawings including a view of the westside of the Parthenon, made in the 16th century, are preserved at the Bibliothèque Royale in Brussels. In the 15th and 16th centuries, however, the attention focused on Rome and it's only from the 17th century onwards that travellers began to visit Greece regularly. Thus Jacob Spon undertook a long voyage through Italy, Dalmatia, Greece and the Levant and in 1678 he published an account titled Voyage d'Italie, de Dalmatie, de Grèce et du Levant of which translations in English, German, Dutch and Italian - amongst other things - clearly show the growing interest in the Greek past. Embassadors at the «Sublime Porte» sent artists to Athens to make drawings of the famous monuments of classical antiquity. Thus, the marquis de Nointel ordered Carrey in 1674 to draw all the sculptures of the Parthenon, the two pediments, the metopes and the frieze ${ }^{1}$. Preserved at the «Bibliothèque nationale» in Paris these drawings are of incomparable value as part of the sculptures were irrevocably mutilated by the Venetian attack and conquest of the acropolis in 1687.

1 F. BROMMER, Die Skulpturen des Parthenon-Giebel, Mainz, 1963, pl. 2, 64; ID., Die Metopen des Parthenon, Mainz, 1967, pl. 149-153; ID., Der Parthenonfries, Mainz, 1977, pl. 6, 48, 110, and 164. 
In the 18 th century travels to Greece continued, yielding the description of Athens by the Frenchman David Le Roy in his Les ruines des plus beaux monuments de la Grèce, published in 1758, and, more important even the work of the English architect James Stuart and of his compatriot the painter Nicolas Revett. Indeed, their four books on The Antiquities of Athens, published between 1762 and 1794, provide us with the first scientific approach of the Athenian ruins (a watercolour of the Erechtheion by Stuart ${ }^{2}$.

In the first part of the 19th century a visit to Greece and a careful study of the surviving monuments became an essential part of the professional training of a Greek Revival artist. Starting for instance at the island of Corfu (town and citadel of Corfu from the port by Schranz around $1840^{3}$ for those travelling through Germany and Northern Italy or at Patras (a street in Patras in 1817 by Williams ${ }^{4}$ for those sailing to the Gulf of Lepanto, the major aim remained Athens, even if the temple of Apollo at Corinth (view of 1833 by Cole $^{5}$ or the treasury of Atreus at Mycenae (the interior of the treasury in 1834 by Dodwell ${ }^{6}$ were visited on the way. It is in Athens in 1811, that the architects Charles Cockerell and Carl Haller von Hallerstein, together with the painter Jakob Linkh, decided to undertake a systematic study of the temple of Aphaia at Aigina, known as the temple of the Panhellenic Jupiter (the Àphaia temple by Cockerell ${ }^{7}$. Once on the spot they saw that the many fallen blocks which encumbered the temple had to be removed before they could start surveying the ruins. During this preliminary work five sculptures of the East pediment and ten of the West pediment came to light, thus substantially enriching our knowledge of the sculpture of that time, or as Haller von Hallerstein put it :

La peine que nous prîmes pour aller au fond des choses... nous valut la chance extraordinaire d'exhumer les magnifiques sculptures qui jadis

\footnotetext{
F.-M. TSIGAKOU, The Rediscovery of Greece, London, 1981, pl. II.

Ibid., pl. VIII.

Ibid., fig. 16.

Ibid., fig. 68.

Ibid., fig. 59.

Ibid., p. 23.
} 
ornaient les deux frontons et de les rendre à l'art moderne. Elles représentent probablement certains héros de la guerre de Troie et portent en général la marque d'une haute antiquité... 8 .

Unfortunately, these sculptures were sold to Ludwig von Bayern. Exhibited in Munich in the 19th century conception of Thorwaldsen, they recovered part of their antique character thanks to the restauration of Dietrich Ohly after World War II ${ }^{9}$.

Equally at the beginning of the 19 th century the Parthenon was deprived of most of its sculptures and the Erechtheion of a column and of a karyatid (view of the Erechtheion by Page in $1818^{10}$ which were shipped to London by lord Elgin in 1803 (lord Elgin's museum at Park Lane in 1808 by Cockerell ${ }^{11}$, causing irreparable damage to these unique Greek temples.

The temple of Bassae was excavated in 1812 by Cockerell and Haller von Hallerstein and the frieze sold to the Trustees of the British Museum.

Apart from all this, travellers, artists, poets and writers continued to describe and extoll the antique monuments and the beauty of Greece.

In 1834, when Athens became the capital of the newly born independant Greek State, excavations started on the acropolis and for years to come most of the attention was spent on these monuments. We have to wait until the last quarter of the 19th century for the excavations of the sanctuaries of Delphi, Delos, Eleusis, Epidaurus and Olympia which will be the principal theme of this conference.

8 G. ROUX, Karl Haller vion Hallerstein. Le temple de Bassae. Publications de la bibliothèque nationale et universitaire de Strasbourg, VI, Strasbouirg, 1976, p. 15.

9 D. OHLY, Die Aegineten. Band I. Die Ostgiebelgruppe, München, 1976; ID., Glyptothek München. Griechische und römische Skulpturen, München, 1972.

10 ANONYMUS, Athens. From the End of the Ancient Era to Greek Independence, Athens, 1985 , p. 36-37.

11 F.-M. TSIGAKOU, op. cit., p. 25. 


\section{Delphi}

Many travellers such as Edward Dodwell in 1801 and Edward Lear in 1849-1850 passed through Delphi but, apart from the majestic scenery - which is in itself evocative of a holy place very little was to be seen at the celebrated site of the sanctuary of Apollo, for, until the end of the 19th century Delphi was overlaid by the village of Kastri (view by Edward Lear 1849-185012). Once the expropriation completed in 1891, the French School of Athens started digging, under the direction of Théophile Homolle, in 1892. The Athenian Treasury was excavated in 1893 and 1894 (reconstruction by Albert Tournière ${ }^{13}$ ) and not only did its foundations come to light, but so did most of the blocs of the walls, two thirds of the triglyphs, all of the metopes - complete and damaged -, as well as parts of the frontons and the cornice. A reconstruction was envisaged, particularly as inscriptions on the antae and on the south wall indicated the exact position of the blocs. The work was given to Replat and executed between 1903 and 1906 with subsidies provided by the municipality of Athens. The enormously rich finds not only yielded valuable architectural information but also included major sculptures such as the «aurige», the sphinx of the Naxiers and so on. The excavation of the temple of Apollo on the other hand left the archaeologists disappointed or as Roux has said :

Les archéologues français qui entreprirent en 1892 la fouille du temple s'attendaient à contempler au moins les vestiges de l'antre ténébreux où prophétisait la Pythie. Ils étaient certains en tout cas de retrouver sous le temple, dans le sol naturel, la <faille> d'où s'exhalait le pneuma inspirateur. Lorsqu'apparurent les soubassements du temple, admirablement conservés, les plus grands espoirs semblaient permis. La déception n'en fut que plus cruelle. Car une fois la fouille achevée, il fallut bien se rendre à l'évidence : de l'adyton il ne restait rien...

Most of the early plans and elevations were done by Albert Tourraine, "prix de Rome» in 1888, in collaboration with Théophile Homolle ${ }^{14}$.

12 Ibid., fig. 19.

13 ANONYMUS, Paris-Rome-Athènes. Le voyage en Grèce des architectes français aux XIXe et XXe siècles, Paris, 1982, p. 300, $\mathrm{n}^{\circ} 13$.

14 Ibid., p. 292-298. 


\section{Delos}

Before the start of the big French excavations in May 1873, several travellers visited Delos. Among the most important ones there is Jean Pitton de Tournefort, a remarkable botanist, whose archaeological map of 1701 was much estimated by Théophile Homolle and Abel Blouet who made a pseudo-plan of the ruins in 182915 published in the third volume of the Expédition scientifique de Morée. Others were Jacob Spon and Georges Wheler in 1675, James Stuart and Nicolas Revett in 1753, Charles Cockerell in 1810 and Haller von Hallerstein between 1814 and 1816. But the fullest description of the ruins was given by a member of the French school, Louis Terrier, in a dissertation of 1864 which unfortunately remained unpublished. Or as René Vallois put it in volume VII of the Exploration Archéologique de Délos :

La plus intelligente et la plus complète description des vestiges antiques

de Délos qui ait été faite avant les fouilles [...].

The French mission under the direction of Albert Lebègue started on the west flank of Mount Kynthos and uncovered some twenty inscriptions giving amongst others the names of Zeus Kynthios and of Athena Kynthia. From 1877 to 1880 most of the precinct of Apollo was uncovered under the direction of Théophile Homolle and the envoy of Henri-Paul Nénot of 1882 notably contains plans of the temenos of Apollo ${ }^{16}$ and a general restauration of which you have a partial view here ${ }^{17}$. In 1882 Salomon Reinach discovered the theatre which was excavated by $\mathbf{J}$. Chamonard in 1892 and 1893, and in 1883 Pierre Paris brought to light the first major house, «La maison des dauphins».

\section{Eleusis}

We get our first glimpse of the ruins of Eleusis in the writings of George Wheeler, who visited the site in 1675 or 1676 .

15 Ibid.., fig. 8.

16 Ibid., p. 259-260.

17 Ibid., p. $261, \mathrm{n}^{\circ} 3$. 
Apparently, he describes the Lesser Propylaea, because the Ionic capitals he mentions occur to correspond to those found by the later expedition of the Society of Dilettanti. He further gives information on a part of a marble statue of the goddess and on a few dedications to Ceres and Proserpine. About one hundred years later, the site again was visited by Richard Chandler, a member of the first expedition of the Dilettanti to Asia Minor. He mentions an amount of marble consisting of fragments of the Doric and Ionic orders, a bust of a colossal statue, representing probably Proserpine, and inscribed pedestals. The ruins and the so-called statue of Proserpine were also seen and described by Edward Dodwell on the occasion of his journey to Greece in 1804. The first real excavations took place in 1812. They were carried out by a mission of the Dilettanti under the direction of William Gell and took place in the Lesser Propylaea and on the site of the temple of Artemis, almost in front of the Greater Propylaea.

But the honour of the systematic and complete excavation of the site belongs to the Greek Archaeological Society of Athens. Between 1882 and 1892. Demetrios Philios, assisted by the architect Wilhelm Dörpfeld, cleared almost entirely the Telesterion, which formed the subject of the envoy of Victor Blavette, «prix de Rome» in 1879, with plans and proposals for elevations (watercolours, frontview and cross-section ${ }^{18}$. This was followed by the investigation of the Southern part of the court of the sanctuary, of the geometric cemetery and of the prehistoric remains to the South of the precinct. Andreas Skias carried out this work between 1894 and 1907. The excavation of the sanctuary was almost completed by Konstantinos Kourouniotes with the help of the architect John Travlos and the ephor John Threpsiades. After World War II the work was continued by Georgios Mylonas, Anastasios Orlandos and John Travlos. So a century and a half of gradually and painstaking work gave us back the most important sanctuary of Demeter and Persephone, but, where once the pilgrim found beautiful temples and imposing marble monuments, the visitor of today will only find a maze of foundations and broken stones.

18 Ibid., p. 275-279. 


\section{Epidauros}

Under the auspices of the Archaeological Society of Athens, Panayotis Kavvadias excavated the sanctuary of Asklepios at Epidaurus from 1881 until his death in 1928.

Alphonse Defrasse sent a study of Epidaurus to the «Ecole des Beaux Arts de Paris» for the years 1891-1893; it notably included an aquarel showing the reconstruction ${ }^{19}$ of the tholos, the temple of Asklepios, the stoa behind, the sacred forest, the temple of Artemis and the propylaea, a plan of the site ${ }^{20}$ and a detailed elevation of the tholos 21 .

\section{Olympia}

The first reference to the site was made by Bernard de Montfaucon in a letter of 14 june 1723 adressed to the archbishop of Corfu, cardinal Quirini :

...mais qu'est-ce que tout cela en comparaison de ce qu'on peut trouver dans la côte de la Morée opposée à ces îles (id est Corfou, Zante, Céphalonie). C'est l'ancienne Elide où se célébraient les jeux olympiques, où l'on dressait une infinité de monuments pour les victorieux, statues, bas-reliefs, inscriptions...

We owe the earliest description of the ruins to Richard Chandler who visited the site in August 1766 and who noted :

The ruin, which we had seen in the evening, we found to be the walls of the cell of a very large temple, standing many feet high and well-built, the stones all injured... From a massive capital remaining it was collected, that the edifice had been of the Doric order... The side is by the road-side, in a green valley between two ranges of even summits pleasantly wooded. The mountain once called Cronium is on the north, and on the south the river Alpheus...

After Chandler a series of English travellers passed through Olympia, among them Leake in 1805, Dodwell in 1806, Cockerell in $1811 \ldots$ A first plan of the site was produced in 1780

19 Ibid., p. 284-285, n 130.

20 Ibid, p. 288.

21 Ibid., p. $287, \mathrm{n}^{\circ} 6$. 
by Barbié du Bocage 22 and a first plan of the temple with a peristylium of 6 on 13 columns was given by Wilkins in his Antiquities of Magna Graecia of 1807.

On May 9th 1829 the team of architects and artists which accompanied the French liberation army started digging in the temple of Jupiter. They uncovered the four corners of the krepis with, on the westside, the basic drums of the peripteros and three of the metopes of the opisthodomos, the one with Herakles offering the birds of lake Stymphalos to Athena, the Nemean lion and the bullmetope. The results of this expedition were published in the Expédition scientifique de Morée.

The Altis of Olympia and the surrounding buildings were finally uncovered by German archaeologists under the leadership of Ernst Curtius and Alfred Adler with the collaboration of the architect Wilhelm Dörpfeld. This took six campaigns ranging from 1875 to 1881 .

They started with the temple of Zeus, followed by the temple of Hera and by the treasuries, and in 1881 most of the site had been unearthed (plan of $1881^{23}$ ).

Vrije Universiteit Brussels

Sektie van Archeologie en

Kunstgeschiedenis

Pleinlaan 2

B - 1050 BRUSSEL

22 H.-V. HERRMANN, Olympia. Heiligtum und Wettkampfstätte, München, 1972, fig. 141 .

23 Ibid., fig. 143. 